\title{
MENINGKATKAN HASIL BELAJAR ALQURAN HADIS MELALUI METODE TAHFIZ DI KELAS II MADRASAH IBTIDAIYAH RAUDHATUL MA'ARIF MUARA BUNGO
}

\author{
Arif Syaifullah \\ Universitas Negeri Padang \\ Email : arifsyaifullah.id@gmail.com \\ Firman Firman \\ Universitas Negeri Padang \\ Email : firman@konselor.org \\ Desyandri \\ Universitas Negeri Padang \\ Email : desyandri@fip.unp.ac.id \\ Fitria Carli Wiseza \\ Institut Agama Islam Yasni Bungo \\ Email: fitriawiseza@gmail.com
}

\begin{abstract}
This research is motivated by the low student learning outcomes in the Alquran Hadis subjects especially in memorizing short chapters which are the target of achieving minimum completeness criteria (KKM). This study aims to improve student learning outcomes by applying the method of tahfiz in the subject of the Alquran Hadis with theory surah Al-kafirun in class II MI Raudhatul Ma'arif Muara Bungo Academic year 2019/2020. This type of research is a Classroom Action Research (CAR) that has been conducted in two cycles. The instrument used was a test of learning outcomes in the form of a test sheet that had been tested for validity and reliability. The results of this study indicate that there was an increase in student learning outcomes in the Alquran Hadis subject with theory Al Kafirun by using the Tahfiz method in class II MI Raudhatul Ma'arif Muara Bungo. Increasing student learning outcomes can be seen changes from cycle I and cycle II. Student learning outcomes after taking action using tahfiz method in the first cycle only 15 students or $65 \%$ were able to reach the KKM and in the second cycle after the improvement was increased to 23 students or $100 \%$ ie all students were able to reach the KKM determined by the school. Thus it was concluded that "using the method of tahfiz on the subject of the Alquran Hadis can improve student learning outcomes in class II Madrasah Ibtidaiyah Raudhatul Ma'arif Muara Bungo at 2019 years".
\end{abstract}

Keywords: Learning Outcomes, Alquran Hadis Subject, Tabfiz Method.

Nur El-Islam, Volume 7, Nomor 2, Oktober 2020 


\begin{abstract}
Penelitian ini dilatarbelakangi oleh rendahnya hasil belajar siswa pada mata pelajaran Alquran Hadis khususnya dalam menghafal surah-surah pendek yang menjadi target tercapainya kriteria ketuntasan minimal. Penelitian ini bertujuan untuk meningkatkan hasil belajar siswa dengan menerapkan metode tahfiz pada mata pelajaran Alquran Hadis materi surah Al-Kafirun di kelas II MI Raudhatul Ma'arif Muara Bungo Tahun Pelajaran 2019/2020. Jenis penelitian yang digunakan adalah Penelitian Tindakan Kelas (PTK) yang telah dilakukan dalam dua siklus. Instrument yang digunakan adalah test hasil belajar berupa lembar tes yang telah diuji validitas dan reliabilitasnya. Hasil penelitian ini menunjukkan bahwa terjadi peningkatan pada hasil belajar siswa mata pelajaran Alquran Hadis materi Surah Al-Kafirun dengan menggunakan metode Tabfiz pada siswa kelas II MI Raudhatul Ma'arif Muara Bungo. Meningkatnya hasil belajar siswa dapat dilihat perubahannya dari siklus I dan siklus II. Hasil belajar siswa setelah dilakukan tindakan dengan menggunakan metode Tahfiz pada siklus I hanya 15 siswa atau 65\% yang mampu mencapai KKM dan pada siklus II setelah dilakukannya perbaikan meningkat menjadi 23 siswa atau $100 \%$ yaitu semua siswa sudah mampu mencapai KKM yang ditentukan sekolah. Dengan demikian disimpulkan bahwa "menggunakan metode tahfiz pada mata pelajaran Alquran Hadis dapat meningkatkan hasil belajar siswa di kelas II Madrasah Ibtidaiyah Raudhatul Ma'arif Muara Bungo tahun 2019”.
\end{abstract}

Kata Kunci: Hasil belajar, Mata pelajaran Alquran Hadis, Metode Tabfiz:

\title{
A. PENDAHULUAN
}

1. Latar Belakang

Mata pelajaran Alquran Hadis di Madrasah Ibtidaiyah adalah salah satu mata pelajaran PAI yang menekankan pada kemampuan membaca dan menulis Alquran dan hadis dengan benar, serta hafalan terhadap surah-surah pendek dalam Alquran. ${ }^{1}$ Dalam pembelajaran Alquran Hadis menghafal Juz 'amma atau surat-surat pendek yang terdapat didalam Alquran Juz 30 adalah sasaran utama dalam tercapainya kriteria ketuntasan minimal (KKM) yang telah ditetapkan oleh MI Raudhatul Ma'arif Bungo. Maka, setiap siswa diinginkan untuk memiliki motivasi yang kuat dan dibantu dengan metode pembelajaran yang tepat untuk tercapainya tujuan pembelajaran tersebut.

${ }^{1}$ Madrasah Ibtidaiyah (MI) Raudhatul Ma'arif, Dokumen I KTSP Kurikulum 13, (Muara Bungo: Raudhatul Ma’arif, 2018), h.18 
Namun pada kenyataannya, berdasarkan hasil observasi peneliti di kelas II MI Raudhatul Ma'arif ketika berlangsungnya mata pelajaran Alquran Hadis ditemukan banyak siswa yang kurang memilki motivasi dalam mengikuti pembelajaran Alquran Hadis. Hal itu terlihat dengan nilai rata-rata kelas pada mata pelajaran Alquran Hadis yang rendah dan hanya 8 siswa dari 23 siswa yang mampu mencapai Kriteria Ketuntasan Minimal (KKM) yaitu 75. Diantara indikator lainnnya adalah siswa hanya mampu membaca dari surat-surat pendek di dalam Juz 30, hanya sebagian siswa yang sudah dapat menghafalnya, ketika diberikan pertanyaan, siswa belum menghafal sepenuhnya ayat-ayat dari setiap surat yang diajarkan gurunya, bahkan ada yang belum hafal sama sekali.

Kondisi demikian apabila terus dibiarkan akan berdampak buruk terhadap kualitas pembelajaran mata pelajaran Alquran Hadist di Kelas II tersebut khususnya, dan di MI Raudhatul Ma'arif secara keseluruhan. Bertitik pada penjelasan diatas, penulis tertarik untuk melakukan penilitian tindakan kelas (PTK) dengan judul: "Meningkatkan hasil belajar Alquran Hadis melalui metode Tahfiz Di Kelas II Madrasah Ibtidaiyah Raudhatul Ma'arif Muara Bungo”

\section{Identifikasi Masalah}

Berdasarkan latar belakang masalah yang telah diuraikan, maka dapat dilakukan identifikasi masalah sebagai berikut: 1) Rendahnya hasil belajar siswa pada Mata Pelajaran Alquran Hadis dengan nilai rata-rata kelas 62,29. 2) Kurangnya minat siswa dalam memperhatikan penjelasan guru pada materi Surah Al-Kafirun. 3) Penyampaian materi yang dilakukan hanya dengan metode konvensional yaitu ceramah dan menulis secara terus menerus. 4) Kurang aktifnya siswa dalam mengikuti proses pembelajaran.

\section{Teori/Kajian}

\section{a. Pengertian Metode Tahfiz}

Secara etimologi, istilah metode berasal dari bahasa Yunani "Metodos". Kata ini terdiri dari dua suku kata : yaitu "metha" yang berarti melalui atau melewati dan "hodos" yang berarti jalan atau cara. 
Metode berarti suatu jalan yang dilalui untuk mencapai tujuan. ${ }^{2}$ Dalam Bahasa Arab Metode disebut “Thariqat”, dalam Kamus Besar Bahasa Indonesia Metode adalah : "Cara yang teratur dan terpikir baik-baik untuk mencapai maksud". ${ }^{3}$

Sedangkan Tahfiz yang berarti menghafal. Menghafal dari kata dasar hafal yang dari bahasa arab hafidza-yahfadzu-hifdzan, yaitu lawan dari lupa, yaitu selalu ingat dan sedikit lupa. ${ }^{4}$ Kata hafalan berasal dari kata "hafal" yang berarti "telah dapat mengucapkan dengan ingatan (tidak usah melihat buku)". Jika diberi akhiran "an" maka berarti mempelajari tentang pelajaran supaya hafal. ${ }^{5}$ Dan juga berarti "berusaha menerapkan ke dalam pikiran agar selalu ingat". 6 Arti $A l-h i f d z$ menurut bahasa tiada bedanya dengan artinya menurut istilah, yaitu "menampakkan dan membacanya luas tanpa kitab".7

Dari paparan tersebut di atas dapat ditarik benang merah bahwa Metode Tahfiz adalah metode yang bertumpu pada kemampuan mengingat dan menyebutkan kembali ingatanya atau hafalanya. Jadi penulis memberikan kesimpulan dari pendapat dan penjelasan diatas bahwa Metode Tahfiz maksudnya ialah suatu cara guru dalam melaksanakan pembelajaran siswa aktif dengan menggunakan daya ingatan yang tajam untuk mencapai suatu tujuan yang diinginkan.

b. Macam-macam Metode Tahfiz

Berbagai macam metode tahfiz yang telah dirumuskan oleh para ahli yang sesuai dengan kebutuhannya masing-masing. Diantaranya adalah: 1) Metode Tahfiz Teknik Takrir. ${ }^{8}$ 2) Metode Tahfiz Teknik

${ }^{2}$ M.Arifin, Ilmu Pendidikan Islam, (Jakarta: Bumi Aksara, 2001), Cet.ke-5, h.61

${ }^{3}$ Departemen Pendidikan dan Kebudayaan, Kamus Besar Bahasa Indonesia, (Jakarta: Balai Pustaka, 2005) ed.ke-2, Cet.ke-4, h.652

${ }^{4}$ Mahmud Yunus, Kamus Arab-Indonesia, (Jakarta: Hidakarya Agung, 2000), h.105

${ }^{5}$ Departemen Pendidikan dan Kebudayaan, Kamus Besar Bahasa Indonesia, (Jakarta: Balai Pustaka, 2008), h.38

${ }^{6}$ Pustaka Pembinaan dan Pengembangan Bahasa Depdikbud, Kamus Besar Bahasa Indonesia, (Jakarta: Balai Pustaka, 2003), Cet ke-4, h.291.

${ }^{7}$ Ibid, h.29.

${ }^{8}$ Sa'dullah, 9 Cara Praktis Menghafal Al-Qur'an, (Jakarta: Gema Insani, 2000), h.17 
Muroja'ah. ${ }^{9}$ 3) Metode Tahfiz Teknik Tasmi' ${ }^{10}$ 4) Metode Tahfiz Teknik Talqin . ${ }^{11}$

Maka, pada penilitian ini penulis memilih metode Tahfiz Teknik Talqin sebagai metode yang akan diterapkan pada pembelajaran Alquran hadis di kelas II MI Raudhatul Ma'arif. Metode Tahfiz Teknik Talqin adalah membacakan atau mendiktekan qira'ah yang dilakukan oleh guru alquran yang mumpuni dan memiliki akurasi bacaan (mutqin), sedangkan para murid mendengarkannya dan kemudian mengikuti bacaannya, hal tersebut dilakuakan secara berulang hingga siswa hafal. ${ }^{12}$

Metode Tahfiz Teknik Talqin dipilih denfan asumsi bahwa teknik tersebut sangat tepat digunakan pada peserta didik yang berusia 8 tahun kebawah, karena pada usia itu rata-rata siswa masih belum bisa membaca alquran dengan benar dan sesuai dengan kaidahnya. Oleh sebab itu, peran guru sangatlah dibutuhkan sebagai mulaqqin (yang mencontohkan bacaan Alquran) agar memudahkan siswa dalam menghafal.

Adapun langkah-langkah yang sistematis dalam penerapan Metode Tahfiz dengan Teknik Talqin adalah 1) Guru membacakan (mencontohkan bacaan) Alquran dihadapan siswa dengan suara yang lantang dan bacaan yang benar. 2) Siswa mendengarkan bacaan Alquran guru dengan seksama dan perhatian yang penuh. 3) Lalu siswa mengikuti bacaan guru dengan persis seperti yang dibacakan kepadanya. 4) Setelah itu siswa membacakan Alquran dihadapan guru, sedangkan guru memperhatikan bacaannya dan meluruskannya

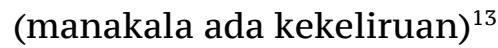

\footnotetext{
${ }^{9}$ Alpiyanto, Menjadi Juara dan Berkarakter, (Bekasi: PT. Tujuh Samudra, 2013), h.184

${ }^{10}$ Wiwi Alwiyah Wahid, Cara Cepat Mebaca Al-Qur'an, (Yogyakarta: Diva Press, 2014), h. 98

${ }^{11}$ Fathin Masyhud dan Ida Husnur Rahmawati, Rahasia Sukses 3 Hafizh Qur'an Cilik Mengguncang Dunia, (Jakarta : Zikrul Hakim, 2017), Cet.ke-4, h.229

${ }^{12}$ Salafuddin AS, Ngaji Metal Metode Talqin , (Jakarta: Wali Pustaka, 2018), Cet.1 , h. $142-143$

${ }^{13}$ Ibid, h.146
} 


\section{c. Hasil Belajar}

Hasil belajar merupakan suatu masalah dalam sejarah kehidupan manusia, karena sepanjang rentang kehidupannya manusia selalu mengejar prestasi menurut bidang dan kemampuan masing-masing. ${ }^{14}$ Mohamad Surya berpendapat bahwa pembelajaran ialah suatu proses berubahnya tingkah laku siswa dari hasil interaksi sesame munusia dengan lingkungan. ${ }^{15}$ Hasil belajar siswa secara nyata dapat dilihat dalam bentuk kuantitas yaitu angka. ${ }^{16}$

Sedangkan menurut Poerwodarminto bahwa: "Hasil belajar adalah hasil yang telah dicapai setelah siswa mendapat pengajaran dalam waktu tertentu". ${ }^{17}$ Hasil pengajaran dapat dikatakan berhasil apabila pengajaran itu mencapai tujuan yang ingin diraih yaitu tujuan belajar. Jadi, dapat disimpulkan bahwa hasil belajar itu adalah suatu perolehan nilai yang diterima oleh peserta didik setelah melewati proses pembelajaran dalam jangka waktu tertentu dan dituangkan kedalam bentuk angka atau nilai.

Benyamin S. Bloom seorang ahli pendidikan yang pahamnya banyak dipergunakan oleh kalangan pendidik, mengklasifikasikan hasil belajar ke dalam tiga ranah yaitu: 1) Hasil Belajar Ranah Kognitif, 2) Hasil Belajar Ranah Afektif, 3) Hasil Belajar Ranah Psikomotorik. ${ }^{18}$ Dari beberapa ranah hasil belajar diatas penulis memilih hasil belajar kognitif sebagai tujuan tercapainya hasil penelitian karena hasil belajar kognitif dapat diukur kemampuan siswa melalui tes yang dilakukan setiap akhir siklus.

${ }^{14}$ Departemen Pendidikan dan Kebudayaan, Kamus Besar Bahasa Indonesia, (Jakarta: Balai Pustaka, 2002), h.1127

${ }^{15}$ Frandy Pratama, Firman, Neviyarni, “Pengaruh Motivasi Belajar IPA Siswa Terhadap Hasil Belajar Di Sekolah Negeri” dalam Edukatif : Jurnal Pendidikan, Vol. I, No. 3, h. 282.

16 Paizaluddin dan Ermalinda, PenelitianTindakan Kelas (Classroom Action Research): Panduan Teoritis dan Praktis, (Bandung: Alfabeta, 2016), Cet.3, h. 211

${ }^{17}$ Poerwadarminto, Kamus Besar Bahasa Indonesia, (Jakarta: Bina Aksara, 2002), h.96

${ }^{18}$ A. Wahab Jufri, Belajar Dan Pembelajaran Sains: Modal Dasar Menjadi Guru Profesional, (Bandung: Pustaka Reka Cipta, 2017), h.75-89 


\section{Tujuan Penelitian}

Adapun tujuan diadakan penilitian tindakan kelas ini adalah sebagai berikut :

1. Untuk mengetahui penerapan Metode Tahfiz yang baik dalam meningkatkan hasil belajar siswa pada mata pelajaran Alquran Hadis di kelas II MI Raudhatul Ma’arif Muara Bungo.

2. Untuk meningkatkan hasil belajar siswa pada mata pelajaran Alquran Hadis di kelas II MI Raudhatul Ma'arif Muara Bungo setelah belajar menggunakan Metode Tahfiz.

\section{B. METODOLOGI}

\section{Metodologi Penelitian}

Jenis penelitian yang dilakukan penulis adalah penelitian tindakan kelas (PTK). Penelitian tindakan kelas (PTK) dipilih karena permasalahan yang terjadi terdapat di dalam kelas. Dengan dilakukannya penelitian tindakan kelas (PTK) dapat mengangkat masalah-masalah yang aktual yang dilakukan oleh para guru secara praktis dan lebih profesional. ${ }^{19}$ Model penelitian yang digunakan oleh penulis ialah model penelitian Stephen Kemmis \& McTaggart yang dilaksanakan dalam 2 siklus pembelajaran.

Teknik pengumpulan data yang digunakan peneliti adalah Tes. Untuk menghitung hasil tes pada proses pembelajaran Alquran Hadis dengan menggunakan Metode Tahfiz, dapat menggunakan rumus percentages correction. ${ }^{20}$

$\mathrm{S}=\frac{R}{N} \times 100$

Keterangan:

$\mathrm{S}=$ nilai yang dicari atau diharapkan

$\mathrm{R}=$ jumlah skor atau item yang dijawab benar

$\mathrm{N}$ = skor maksimum ideal dari tes yang bersangkutan

$100=$ konstanta (bilangan tetap) .

19 Taniredja, T., dkk, "Pendidikan Kewarganegaraan di Perguruan Tinggi Muhammadiyah (Bandung: Alfabeta, 2010), h. 16-17

${ }^{20}$ Ngalim M. Purwanto, Prinsip-Prinsip dan Teknik Evaluasi Pengajaran (Bandung: PT Remaja Rosdakarya, 2004), h. 112 
Sedangkan untuk menghitung nilai rata-rata kelas yaitu dengan cara menjumlahkan seluruh nilai hasil belajar yang diperoleh siswa kemudian dibagi dengan jumlah seluruh siswa dikelas dengan rumus sebagai berikut:

Nilai rata-rata $=\frac{\text { jumlah seluruh nilai hasil belajar siswa }}{\text { jumlah seluruh } \text { siswa }}$

Setelah diketahui rata-rata tingkat hasil belajar siswa seluruhnya, maka dapat dihitung persentase ketuntasan hasil belajar siswa digunakan rumus sebagai berikut : ${ }^{21}$

Persentase ketuntasan hasil belajar $=\frac{\text { jumlah siswa yang tuntas }}{\text { jumlah seluruh siswa }} X 100$

Tabel 1 Persentase Ketuntasan Hasil Belajar ${ }^{22}$

\begin{tabular}{|c|c|c|}
\hline $\begin{array}{c}\text { Tingkat } \\
\text { Penguasaan }\end{array}$ & Nilai Huruf & Predikat \\
\hline $86-100 \%$ & A & Sangat Baik \\
$76-85 \%$ & B & Baik \\
$60-75 \%$ & C & Cukup \\
$55-59 \%$ & D & Kurang \\
$\leqslant 54 \%$ & E & Kurang Sekali \\
\hline
\end{tabular}

Instrumen Penelitian yang digunakan penilitian ini untuk mengumpulkan data yang valid ialah Lembar Tes. Lembar soal disusun berdasarkan kisi-kisi soal tes evaluasi belajar. Lembar soal diberikan kepada siswa untuk mengetahui hasil belajar siswa sebelum dan sesudah diberi tindakan dengan menerapkan Metode Tahfiz pada siswa kelas II MI Raudhatul Ma’arif Muara Bungo.

Tabel 2 Kisi-kisi Butiran Soal

\begin{tabular}{|c|c|c|c|}
\hline Aspek & Kompetensi Dasar & $\begin{array}{c}\text { Indikator Pencapaian } \\
\text { Kompetensi }\end{array}$ & $\begin{array}{c}\text { Item } \\
\text { Butiran } \\
\text { Soal }\end{array}$ \\
\hline
\end{tabular}

${ }^{21}$ Kunandar, Penilaian Autentik (Jakarta: PT Raja Grafindo Persada, 2013), h. 151

${ }^{22}$ Purwanto, Prinsip-prinsip Teknik Evaluasi Pengajaran, h. 103 
Meningkatkan Hasil Belajar ...

\begin{tabular}{|l|l|l|l|}
\hline Kognitif & $\begin{array}{l}\text { 3.3. Mengenal Q.S. } \\
\text { al- Kafirun (109) }\end{array}$ & $\begin{array}{l}\text { 1) Membaca Q.S. } \\
\text { al- Kafirun (109) } \\
\text { 2) Memahami makna } \\
\text { yang terkandung dalam } \\
\text { surat al- Kafirun (109) } \\
\begin{array}{l}\text { Q.S. al- } \\
\text { Kafirun(109) secara } \\
\text { benar dan fasih }\end{array}\end{array}$ & $\begin{array}{l}\text { 3) Menghafalkan Q.S } \\
\text { al- Kafirun (109) beserta } \\
\text { artinya }\end{array}$ \\
\hline
\end{tabular}

Teknik Analisis data yang digunakan dalam penelitian ini ialah deskriptif kualitatif dan kuantitatif. Analisis data kuantitatif berupa data perhitungan (angka) sederhana yang diuraikan secara deskriptif. Penilaian Hasil Belajar siswa dilakukandengan menggunakan tes tulis berupa soal pilihan ganda yang berjumlah 10 butir soal dan essay yang berjumlah 5 butir soal. Skor untuk pilihan ganda adalah 6 jika benar satu dan 60 jika benar semuanya. Sedangkan skor untuk essay adalah 8 jika benar 1 soal dan skor 40 jika benar semua. Maka, total keseluruhan skor yang ingin dicapai adalah 100.

Untuk menghitung nilai yang diperoleh siswa yaitu menggunakan rumus:

$\mathrm{S}=\frac{R}{N} \times 100$

Keterangan:

$\mathrm{S}=$ nilai yang dicari atau diharapkan

$\mathrm{R}=$ jumlah skor atau item yang dijawab benar

$\mathrm{N}$ = skor maksimum ideal dari tes yang bersangkutan

$100=$ konstanta (bilangan tetap) ${ }^{23}$

Sedangkan untuk menghitung nilai rata-rata kelas yaitu dengan cara menjumlahkan seluruh nilai hasil belajar yang diperoleh siswa kemudian dibagi dengan jumlah seluruh siswa dikelas dengan rumus sebagai berikut:

Nilai rata-rata $=\frac{\text { jumlah seluruh nilai hasil belajar siswa }}{\text { jumlah seluruh siswa }}$

${ }^{23}$ Purwanto, Prinsip-Prinsip dan Teknik Evaluasi Pengajaran, h. 112 
Setelah diketahui rata-rata tingkat hasil belajar siswa seluruhnya, maka dapat dihitung persentase ketuntasan hasil belajar siswa digunakan rumus sebagai berikut:

Persentase Ketuntasan Hasil Belajar $=\frac{\text { jumlah siswa yang tuntas }}{\text { jumlah seluruh siswa }} X 100^{24}$

Tabel 3 Persentase Ketuntasan Hasil Belajar ${ }^{25}$

\begin{tabular}{|c|c|c|}
\hline $\begin{array}{c}\text { Tingkat } \\
\text { Penguasaan }\end{array}$ & Nilai Huruf & Predikat \\
\hline $86-100 \%$ & A & Sangat Baik \\
$76-85 \%$ & B & Baik \\
$60-75 \%$ & C & Cukup \\
$55-59 \%$ & D & Kurang \\
$\leqslant 54 \%$ & E & Kurang Sekali \\
\hline
\end{tabular}

\section{Hipotesis Tindakan}

Berdasarkan teori pembelajaran dan hasil penelitian yang telah dipaparkan pada latar belakang penelitian sebelumnya, peneliti dapat menyusun hipotesis tindakan yaitu hasil belajar siswa akan meningkat dengan penerapan Metode Tahfiz pada mata pelajaran Alquran Hadis di kelas II MI Raudhatul Ma'arif.

\section{PEMBAHASAN}

1. Temuan Penelitian

\section{a. Hasil Penelitian Tindakan Siklus I}

Tindakan siklus I dilaksanakan tiga kali pertemuan. Pertemuan pertama dilaksanakan pada hari Rabu, 02 Oktober 2019, pertemuan kedua pada hari Kamis, 03 Oktober 2019 dan pertemuan ketiga pada hari Jum'at 04 Oktober 2019.

\section{1) Deskripsi Tindakan Siklus I Pertemuan 1}

Pertemuan pertama dilaksanakan pada hari Rabu, 02 Oktober 2019 dimulai pada pukul 08.00-09.10. Dengan siswa yang hadir sebanyak 23 orang yang terdiri atas 13 siswa laki-laki, dan 10 siswi

\footnotetext{
${ }^{24}$ Kunandar, Penilaian Autentik, h. 151

${ }^{25}$ Purwanto, Prinsip-prinsip Teknik Evaluasi Pengajaran, h. 103
} 
perempuan. Guru berperan sebagai pelaksana tindakan kegiatan pembelajaran yaitu Arif Syaifullah (Peneliti). Sedangkan bertugas sebagai pengamat selama kegiatan berlangsung yaitu Guru Pengampu Mata Pelajaran Alquran Hadis Bapak Kaspul Anwar, S.Pd (Observer). Setiap kegiatan terdiri proses-proses dan urutan yang tertera dalam Rencana Pelaksanaan Pembelajaran. Dalam tahap ini peneliti melakukan tindakan-tindakan yaitu melakukan proses belajar mengajar sesuai dengan langkah-langkah pembelajaran menggunakan Metode yang peneliti lakukan adalah sebagai berikut:

Kegiatan awal yang di lakukan oleh guru adalah memberikan salam, tegur sapa dan mengajak semua siswa berdo'a, mengecek lembar kehadiran siswa, memberikan motivasi siswa sebelum dimulai pembelajaran, menyampaikan tujuan pembelajaran dan menyampaikan materi pembelajaran yaitu Surah Al-Kafirun dengan pembahasan "membaca Surah Al-Kafirun dengan bacaan yang baik dan benar".

Tahap selanjutnya yaitu kegiatan inti, pada tahap ini guru memulai dengan mencontohkan bacaan Surah Al-Kafirun dan Siswa Menyimak bacaan dan mencermati bacaan surah Al- Kafirun (109), dan Siswa Mencermati lafal ayat surah Al- Kafirun (109). Selanjutnya Guru menampilkan gambar tulisan Surah Al- Kafirun, Guru meminta siswa untuk membacakan surah Al- Kafirun ayat demi ayat secara bersama-sama, dan guru mengajukan pertanyaan terkait hukum tajwid yang terkandung dalam Surah Al-Kafirun .

Pada aspek eksplorasi, Guru mencontohkan bacaan surah AlKafirun ayat demi ayat, kemudian siswa mengikuti bacaan guru, dan guru mendengarkan bacaan siswa satu persatu. Selanjutnya guru menyuruh siswa untuk menulis lafal Al- Kafirun (109 dibuku tulisnya masing-masing, setelah siswa menulis guru menyuruh siswa untuk membacakan nya satu persatu di depan kelas.

Kegiatan terakhir ialah kegiatan penutup, pada tahap ini guru memberikan kesempatan kepada siswa yang ingin menyimpulkan materi pembelajaran, dan memberikan kesempatan kepada siswa untuk bertanya jawab tentang materi yang telah dipelajari, kemudian 
guru menutup pembelajaran dengan mengucapkan hamdalah dan mengucapkan salam.

\section{2) Deskripsi Tindakan Siklus I Pertemuan 2}

Pertemuan kedua dilaksanakan pada hari Kamis, 03 Oktober 2019 dimulai pada pukul 08.00-09.10. Dengan siswa yang hadir sebanyak 21 orang yang terdiri atas 13 siswa laki-laki, 8 siswi perempuan dan 2 orang siswi yang izin karena sakit. Guru berperan sebagai pelaksana tindakan kegiatan pembelajaran yaitu Arif Syaifullah (Peneliti). Sedangkan bertugas sebagai pengamat selama kegiatan berlangsung yaitu Guru Pengampu Mata Pelajaran Alquran Hadis Bapak Kaspul Anwar, S.Pd (Observer). Setiap kegiatan terdiri proses-proses dan urutan yang tertera dalam Rencana Pelaksanaan Pembelajaran. Dalam tahap ini peneliti melakukan tindakan-tindakan yaitu melakukan proses belajar mengajar sesuai dengan langkahlangkah pembelajaran menggunakan Metode yang peneliti lakukan adalah sebagai berikut:

Kegiatan awal yang di lakukan oleh guru adalah memberikan salam, tegur sapa dan mengajak semua siswa berdo'a, mengecek lembar kehadiran siswa, memberikan motivasi siswa sebelum dimulai pembelajaran, menyampaikan tujuan pembelajaran dan menyampaikan materi pembelajaran yaitu Surah Al-Kafirun dengan pembahasan "Menunujukkan arti Mufrodat dan menjelaskan isi kandungan Surah Al-Kafirun".

Tahap selanjutnya yaitu kegiatan inti, pada tahap ini guru memulai dengan mencontohkan bacaan Surah Al-Kafirun dan Siswa Menyimak bacaan dan mencermati bacaan surah Al- Kafirun. Selanjutnya Guru menampilkan gambar tulisan Surah Al- Kafirun, Guru meminta siswa untuk membacakan surah Al- Kafirun beserta arti dan maknanya, dan guru mengajukan pertanyaan terkait arti yang terkandung dalam Surah Al-Kafirun .

Pada aspek eksplorasi, Guru Menunjukkan arti mufradat Surah Al- Kafirun (109), kemudian guru membacakan arti surah Al-Kafirun, kemudian siswa mengikuti bacaan guru. Selanjutnya guru menyuruh siswa untuk menulis arti Surah Al- Kafirun (109) dan isi kesimpulan kandungan Al- Kafirun di buku tulisnya masing-masing, setelah siswa 
menulis guru menyuruh siswa untuk membacakan tulisannnya satu persatu di depan kelas.

Kegiatan terakhir ialah kegiatan penutup, pada tahap ini guru memberikan kesempatan kepada siswa yang ingin menyimpulkan materi pembelajaran, dan memberikan kesempatan kepada siswa untuk bertanya jawab tentang materi yang telah dipelajari, kemudian guru menutup pembelajaran dengan mengucapkan hamdalah dan mengucapkan salam.

\section{3) Deskripsi Tindakan Siklus I Pertemuan 3}

Pertemuan ketiga dilaksanakan pada hari Jumat, 04 Oktober 2019 dimulai pada pukul 08.00-09.10. Dengan siswa yang hadir sebanyak 23 orang yang terdiri atas 13 siswa laki-laki, dan 10 siswi perempuan. Guru berperan sebagai pelaksana tindakan kegiatan pembelajaran yaitu Arif Syaifullah (Peneliti). Sedangkan bertugas sebagai pengamat selama kegiatan berlangsung yaitu Guru Pengampu Mata Pelajaran Alquran Hadis Bapak Kaspul Anwar, S.Pd (Observer). Setiap kegiatan terdiri proses-proses dan urutan yang tertera dalam Rencana Pelaksanaan Pembelajaran. Dalam tahap ini peneliti melakukan tindakan-tindakan yaitu melakukan proses belajar mengajar sesuai dengan langkah-langkah pembelajaran menggunakan Metode yang peneliti lakukan adalah sebagai berikut:

Kegiatan awal yang di lakukan oleh guru adalah memberikan salam, tegur sapa dan mengajak semua siswa berdo'a, mengecek lembar kehadiran siswa, memberikan motivasi siswa sebelum dimulai pembelajaran, menyampaikan tujuan pembelajaran dan menyampaikan materi pembelajaran yaitu Surah Al-Kafirun dengan pembahasan "Menghafal Surah Al-Kafirun dengan Metode Tahfiz Teknik Talqin”.

Tahap selanjutnya yaitu kegiatan inti, pada tahap ini guru memulai dengan mencontohkan bacaan Surah Al-Kafirun dan Siswa Menyimak bacaan dan mencermati bacaan surah Al- Kafirun dengan memperhatikan makhraj dan hokum tajwidnya. Selanjutnya guru meminta siswa untuk membacakan surah Al- Kafirun beserta arti dan maknanya, dan guru mengajukan pertanyaan terkait hukum tajwid dan makna yang terkandung dalam Surah Al-Kafirun . 
Pada aspek eksplorasi, guru memulai dengan membacakan (mencontohkan bacaan) Surah Al-Kafirun ayat demi ayat dengan suara yang lantang dan bacaan yang benar, kemudian siswa mendengarkan bacaan guru dengan seksama, dan guru menyuruh siswa untuk mengikuti bacaan yang dicontohkan ayat per ayat tanpa melihat teks, kemudian guru mengulangi bacaannya dan siswa mengikuti bacaan guru. Selanjutnya guru mendengarkan hafalan siswa satu persatu di depan kelas, dan guru mekonfirmasikan hafalan siswa yang salah dan memperbaikinya.

Kegiatan terakhir ialah kegiatan penutup, pada tahap ini guru memberikan kesempatan kepada siswa yang ingin menyimpulkan materi pembelajaran, dan memberikan kesempatan kepada siswa untuk bertanya jawab tentang materi yang telah dipelajari, selanjutnya guru memberikan lembar Soal kepada masing-masing siswa sebagai evaluasi hasil belajar pada pembelajaran Bab Surah AlKafirun, setelah siswa mengumpulkan lembar soal dan jawaban yang sudah dikerjakannya, kemudian guru menutup pembelajaran dengan mengucapkan hamdalah dan mengucapkan salam.

\section{4) Pengamatan Hasil Ketuntasan Belajar Siswa}

Tingkat ketuntasan belajar siswa melalui penggunaan Metode Tahfiz dengan Teknik Talqin diketahui dengan menganalisis hasil tes yang telah diberikan kepada siswa. Untuk melihat persentase ketuntasan belajar siswa pada siklus I dapat dilihat pada tabel sebagai berikut:

Tabel 4 Rentang Nilai Hasil Belajar Siswa Siklus I

\begin{tabular}{|c|c|c|}
\hline Interval Nilai & Jumlah Siswa & Keterangan \\
\hline $0-55$ & 4 & Tidak Tuntas \\
\hline $56-69$ & 4 & Tidak Tuntas \\
\hline $70-85$ & 13 & Tuntas \\
\hline $86-100$ & 2 & Tuntas \\
\hline
\end{tabular}


Berdasarkan tabel diatas dapat diketahui bahwa pada siklus I pembelajaran Alquran Hadis yang disajikan dengan Metode Tahfiz di kelas II Madrasah Ibtidaiyah Raudhatul Ma'arif Muara Bungo, terdapat 8 orang siswa yang belum tuntas dengan persentase $35 \%$, sedangkan 15 orang siswa telah mencapai tingkat ketuntasan minimal dengan persentase 65\%. Berdasarkan Kriteria Ketuntasan Minimal (KKM) yang ditetapkan di Madrasah Ibtidaiyah Raudhatul Ma'arif Muara Bungo, bahwa seorang siswa dikatakan tuntas pembelajarannya, bila sudah mencapai dengan nilai ketuntasan minimal 75 (KKM Mata Pelajaran Alquran Hadis). Oleh karena itu dapat disimpulkan bahwa ketuntasan belajar siswa untuk siklus I belum tuntas.

Pencapaian hasil belajar siswa yang terjadi dalam siklus I dapat tergambar oleh diagram sebagaimana berikut:

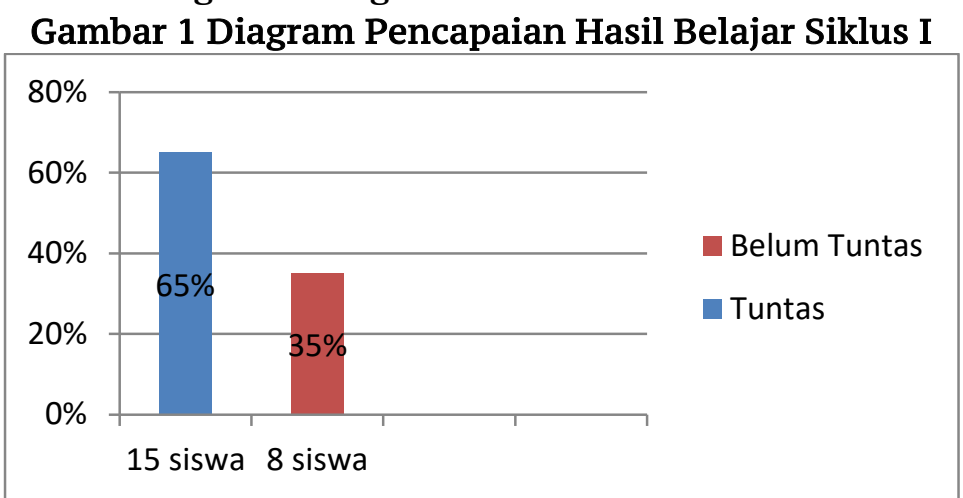

Hasil ketuntasan belajar siswa pada pembelajaran Alquran Hadis untuk siklus I yaitu 65\% dengan nilai rata-rata kelas 68,5. Namun hasil belajar ketuntasan minimal belum mencapai $75 \%$ dari jumlah keseluruhan siswa. Berikut penjelasan tentang hasil temuan untuk aspek-aspek yang perlu diperbaiki selama proses pembelajaran pada siklus I dapat dilihat pada tabel berikut:

Tabel 5 Hasil Temuan dan Revisi selama Proses Pembelajaran Alquran Hadis dengan Menggunakan Metode Tahfiz pada Siklus I

\begin{tabular}{|c|c|cc|cc|}
\hline NO. & Refleksi & \multicolumn{2}{|c|}{ Kegiatan } & \multicolumn{2}{|c|}{ Perbaikan } \\
\hline 1. & Hasil Belajar & 1. & Hasil belajar & 1. & Hasil belajar \\
\hline
\end{tabular}




\begin{tabular}{|l|l|l|l|}
\hline Siswa & siswa pada & siswa \\
& pembelajaran Alquran & pembelajaran Alquran \\
& Hadis untuk siklus I & Hadis untuk siklus I \\
& dengan nilai rat-rata & belum tuntas dan akan \\
& 68,5 dan belum diperbaiki pada siklus \\
& mencapai 75\% dari \\
& jumlah keseluruhan \\
& siswa & II \\
\hline
\end{tabular}

\section{b. Hasil Penelitian Tindakan Siklus II.}

Setelah mempersiapkan beberapa perencanaan yang matang, maka langkah selanjutnya adalah melakukan penelitian tindakan siklus II. Pada Tindakan siklus II ini dilaksanakan dengan tiga kali pertemuan. Pertemuan pertama dilaksanakan pada hari Rabu, 09 Oktober 2019, pertemuan kedua pada hari Kamis, 10 Oktober 2019 dan pertemuan ketiga pada hari Jum'at 11 Oktober 2019.

\section{1) Deskripsi Tindakan Siklus II Pertemuan 1}

Pertemuan pertama dilaksanakan pada hari Rabu, 09 Oktober 2019 dimulai pada pukul 08.00-09.10. Dengan siswa yang hadir sebanyak 20 orang yang terdiri atas 10 siswa laki-laki, 10 siswi perempuan dan 3 orang siswa yang izin tidak mengikuti pembelajaran. Guru berperan sebagai pelaksana tindakan kegiatan pembelajaran yaitu Arif Syaifullah (Peneliti). Sedangkan bertugas sebagai pengamat selama kegiatan berlangsung yaitu Guru Pengampu Mata Pelajaran Alquran Hadis Bapak Kaspul Anwar, S.Pd (Observer).

Setiap kegiatan terdiri proses-proses dan urutan yang tertera dalam Rencana Pelaksanaan Pembelajaran. Dalam Siklus II di pertemuan Pertama ini peneliti melakukan tindakan-tindakan dalam proses belajar mengajar sesuai dengan langkah-langkah pembelajaran menggunakan Metode Tahfiz yang peneliti lakukan adalah sebagai berikut:

Kegiatan awal yang di lakukan oleh guru adalah memberikan salam, tegur sapa dan mengajak semua siswa berdo'a, mengecek lembar kehadiran siswa, memberikan motivasi siswa sebelum dimulai pembelajaran, menyampaikan tujuan pembelajaran dan 
menyampaikan materi pembelajaran yaitu Surah Al-Kafirun dengan pembahasan "Membaca Surah Al-Kafirun dengan bacaan yang benar dan memahami makna yang terkandung di dalam Surah Al-Kafirun”.

Tahap selanjutnya yaitu kegiatan inti, pada tahap ini guru memulai dengan mencontohkan bacaan Surah Al-Kafirun dan Siswa Menyimak bacaan dan mencermati bacaan surah Al- Kafirun (109), dan Siswa Mencermati lafal ayat surah Al- Kafirun (109). Selanjutnya Guru menampilkan gambar tulisan Surah Al- Kafirun, Guru meminta siswa untuk membacakan surah Al- Kafirun ayat demi ayat secara bersama-sama, dan guru mengajukan pertanyaan terkait hukum tajwid yang terkandung dalam Surah Al-Kafirun .

Pada aspek eksplorasi, Guru mencontohkan bacaan surah AlKafirun ayat demi ayat, kemudian siswa mengikuti bacaan guru, dan guru mendengarkan bacaan siswa satu persatu. Selanjutnya guru membacakan arti surah al-Kafirun dan siswa mengikuti bacaan guru. Kemudian guru menyuruh siswa untuk menulis lafal Al- Kafirun (109 beserta artinya dibuku tulisnya masing-masing, setelah siswa menulis guru menyuruh siswa untuk membacakan nya satu persatu di depan kelas.

Kegiatan terakhir ialah kegiatan penutup, pada tahap ini guru memberikan kesempatan kepada siswa yang ingin menyimpulkan materi pembelajaran, dan memberikan kesempatan kepada siswa untuk bertanya jawab tentang materi yang telah dipelajari, kemudian guru menutup pembelajaran dengan mengucapkan hamdalah dan mengucapkan salam.

\section{2) Deskripsi Tindakan Siklus II Pertemuan 2}

Pertemuan kedua dilaksanakan pada hari Kamis, 10 Oktober 2019 dimulai pada pukul 08.00-09.10. Dengan siswa yang hadir sebanyak 21 orang yang terdiri atas 13 siswa laki-laki, 8 siswi perempuan dan 2 orang siswi yang izin karena sakit. Guru yang berperan sebagai pelaksana tindakan kegiatan pembelajaran yaitu Arif Syaifullah (Peneliti). Sedangkan bertugas sebagai pengamat selama kegiatan berlangsung yaitu Guru Pengampu Mata Pelajaran Alquran Hadis Bapak Kaspul Anwar, S.Pd (Observer). 
Setiap kegiatan terdiri proses-proses dan urutan yang tertera dalam Rencana Pelaksanaan Pembelajaran. Dalam tahap ini peneliti melakukan tindakan-tindakan yaitu melakukan proses belajar mengajar sesuai dengan langkah-langkah pembelajaran menggunakan Metode yang peneliti lakukan adalah sebagai berikut:

Kegiatan awal yang di lakukan oleh guru adalah memberikan salam, tegur sapa dan mengajak semua siswa berdo'a, mengecek lembar kehadiran siswa, memberikan motivasi siswa sebelum dimulai pembelajaran, menyampaikan tujuan pembelajaran dan menyampaikan materi pembelajaran yaitu Surah Al-Kafirun dengan pembahasan "Menghafal ayat Surah Al-Kafirun dengan Metode Tahfiz Teknik Talqin".

Tahap selanjutnya yaitu kegiatan inti, pada tahap ini guru memulai dengan mencontohkan bacaan Surah Al-Kafirun dan Siswa Menyimak bacaan dan mencermati bacaan surah Al- Kafirun dengan memperhatikan makhraj dan hukum tajwidnya. Selanjutnya guru meminta siswa untuk membacakan surah Al- Kafirun beserta arti dan maknanya, dan guru mengajukan pertanyaan terkait hukum tajwid dan makna yang terkandung dalam Surah Al-Kafirun .

Pada aspek eksplorasi, guru memulai dengan membacakan (mencontohkan bacaan) Surah Al-Kafirun ayat demi ayat dengan suara yang lantang dan bacaan yang benar, kemudian siswa mendengarkan bacaan guru dengan seksama, dan guru menyuruh siswa untuk mengikuti bacaan yang dicontohkan ayat per ayat tanpa melihat teks, kemudian guru mengulangi bacaannya dan siswa mengikuti bacaan guru. Selanjutnya guru mendengarkan hafalan siswa satu persatu di depan kelas, dan guru mekonfirmasikan hafalan siswa yang salah dan memperbaikinya.

Kegiatan terakhir ialah kegiatan penutup, pada tahap ini guru memberikan kesempatan kepada siswa yang ingin menyimpulkan materi pembelajaran, dan memberikan kesempatan kepada siswa untuk bertanya jawab tentang materi yang telah dipelajari, kemudian guru menutup pembelajaran dengan mengucapkan hamdalah dan mengucapkan salam. 


\section{3) Deskripsi Tindakan Siklus II Pertemuan 3}

Pertemuan ketiga dilaksanakan pada hari Kamis, 11 Oktober 2019 dimulai pada pukul 08.00-09.10. Dengan siswa yang hadir sebanyak 21 orang yang terdiri atas 13 siswa laki-laki, 8 siswi perempuan dan 2 orang siswi yang Alpa. Guru yang berperan sebagai pelaksana tindakan kegiatan pembelajaran yaitu Arif Syaifullah (Peneliti). Sedangkan bertugas sebagai pengamat selama kegiatan berlangsung yaitu Guru Pengampu Mata Pelajaran Alquran Hadis Bapak Kaspul Anwar, S.Pd (Observer).

Setiap kegiatan terdiri proses-proses dan urutan yang tertera dalam Rencana Pelaksanaan Pembelajaran. Dalam tahap ini peneliti melakukan tindakan-tindakan yaitu melakukan proses belajar mengajar sesuai dengan langkah-langkah pembelajaran menggunakan Metode yang peneliti lakukan adalah sebagai berikut:

Kegiatan awal yang di lakukan oleh guru adalah memberikan salam, tegur sapa dan mengajak semua siswa berdo'a, mengecek lembar kehadiran siswa, memberikan motivasi siswa sebelum dimulai pembelajaran, menyampaikan tujuan pembelajaran dan menyampaikan materi pembelajaran yaitu Surah Al-Kafirun dengan pembahasan "Menghafal ayat Surah Al-Kafirun beserta artinya dengan Metode Tahfiz Teknik Talqin".

Tahap selanjutnya yaitu kegiatan inti, pada tahap ini guru memulai dengan mencontohkan bacaan ayat Surah Al-Kafirun dan Siswa Menyimak bacaan dan mencermati bacaan surah Al- Kafirun dengan memperhatikan makhraj dan hukum tajwidnya. Selanjutnya guru meminta siswa untuk membacakan surah Al- Kafirun beserta arti dan maknanya, dan guru mengajukan pertanyaan terkait hukum tajwid dan makna yang terkandung dalam Surah Al-Kafirun .

Pada aspek eksplorasi, guru memulai dengan membacakan (mencontohkan bacaan) Surah Al-Kafirun ayat demi ayat dengan suara yang lantang dan bacaan yang benar, kemudian siswa mendengarkan bacaan guru dengan seksama, dan guru menyuruh siswa untuk mengikuti bacaan yang dicontohkan ayat per ayat tanpa melihat teks, kemudian guru mengulangi bacaannya dan siswa mengikuti bacaan guru. Kemudian guru membacakan arti surah Al-Kafirun dan siswa 
mengikuti bacaan guru. Selanjutnya guru mendengarkan hafalan siswa satu persatu di depan kelas, dan guru mekonfirmasikan hafalan siswa yang salah dan memperbaikinya.

Kegiatan terakhir ialah kegiatan penutup, pada tahap ini guru memberikan kesempatan kepada siswa yang ingin menyimpulkan materi pembelajaran, dan memberikan kesempatan kepada siswa untuk bertanya jawab tentang materi yang telah dipelajari, selanjutnya guru memberikan lembar Soal kepada masing-masing siswa sebagai evaluasi hasil belajar pada pembelajaran Bab Surah AlKafirun, setelah siswa mengumpulkan lembar soal dan jawaban yang sudah dikerjakannya, kemudian guru menutup pembelajaran dengan mengucapkan hamdalah dan mengucapkan salam.

4) Pengamatan Hasil Ketuntasan Belajar Siswa

Tingkat ketuntasan belajar siswa melalui penerapan Metode Tahfiz diketahui dengan menganalisis hasil tes yang diberikan kepada siswa setelah penggunaan Metode Tahfiz. Untuk melihat persentase ketuntasan belajar siswa pada siklus II dapat dilihat pada tabel sebagai berikut:

Tabel 6 Rentang Nilai Hasil Belajar Siswa Siklus II

\begin{tabular}{|c|c|c|}
\hline Interval Nilai & Jumlah Siswa & Keterangan \\
\hline $0-55$ & 0 & Tidak Tuntas \\
\hline $56-69$ & 0 & Tidak Tuntas \\
\hline $70-85$ & 15 & Tuntas \\
\hline $86-100$ & 8 & Tuntas \\
\hline
\end{tabular}

Berdasarkan tabel diatas dapat diketahui bahwa pada siklus II pembelajaran Alquran Hadis yang disajikan dengan Metode Tahfiz di kelas II Madrasah Ibtidaiyah Raudhatul Ma'arif Muara Bungo sudah mengalami peningkatan dari siklus sebelumnya, dengan nilai rata-rata kelas pada mata pelajaran Alquran Hadis yaitu 83,91, dimana 23 siswa-siswi kelas II sudah mampu mencapai target Kriteria Ketuntasan 
Minimal yang telah di tentukan sekolah. Berdasarkan Kriteria Ketuntasan Minimal (KKM) yang ditetapkan di Madrasah Ibtidaiyah Raudhatul Ma'arif Muara Bungo, bahwa seorang siswa dikatakan tuntas pembelajarannya, bila sudah mencapai dengan nilai ketuntasan minimal 75 (KKM Mata Pelajaran Alquran Hadis). Oleh karena itu dapat disimpulkan bahwa ketuntasan belajar siswa untuk siklus II ini tuntas.

Pencapaian hasil belajar siswa yang terjadi dalam siklus II dapat tergambar oleh diagram sebagaimana berikut:

Gambar 2 Diagram Pencapaian Hasil Belajar Siklus II

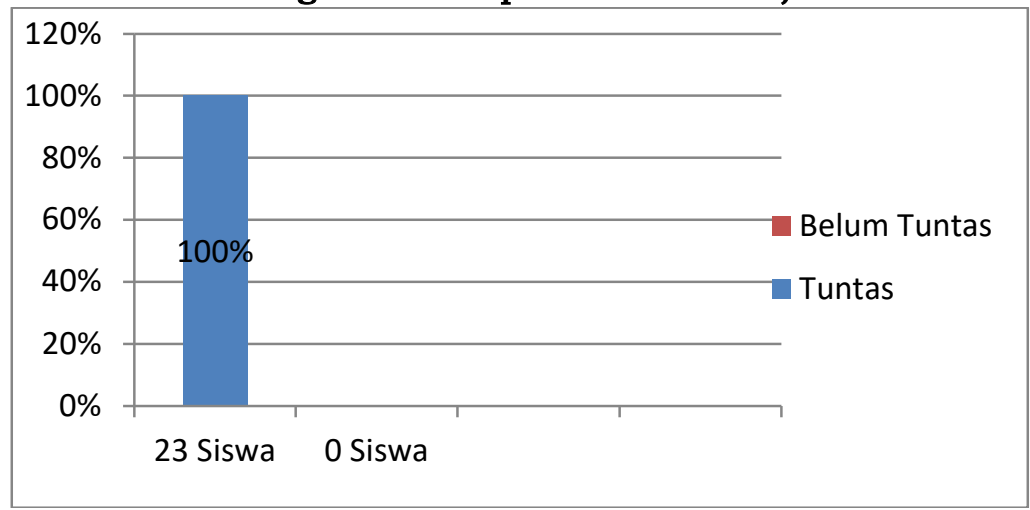

2. Pembahasan

Penelitian tentang meningkatkan hasil belajar Alquran Hadis pada materi Surah Al-Kafirun dengan menerapkan Metode Tahfiz pada siswa kelas II di Madrasah Ibtidaiyah Raudhatul Ma'arif Muara Bungo telah selesai dilaksanakan. Hasil penelitian tersebut membuktikan bahwa dengan menggunakan Metode Tahfiz pada mata pelajaran Alquran Hadis materi Surah Al-Kafirun menunjukkan perubahan yang signifikan pada hasil belajar siswa. Perubahan signifikan tersebut dapat dilihat dari data Siklus I dan Siklus II.

Perolehan hasil belajar Siklus I yang mencapai KKM sebanyak 15 siswa atau 65\%, dan 8 atau 35\% siswa masih belum mampu mencapai Kriteria Ketuntasan Minimal yang sudah di tentukan sekolah. Nilai tertinggi pada siklus I adalah 92 dan nilai terendah adalah 52. Dari 15 siswa yang mencapai KKM, 2 siswa memperoleh nilai 92, 8 siswa 
memperoleh nilai 84, 5 siswa memperoleh nilai 78. Jumlah siswa yang belum mencapai KKM sebanyak 8 siswa atau 35\%. Siswa yang belum mencapai KKM memperoleh nilai antara 52-66. Siswa yang memperoleh nilai 66 sebanyak 2 siswa, siswa yang memperoleh nilai 64 sebanyak 2 siswa dan, 4 orang siswa yang memperoleh nilai 52 .

Perolehan hasil belajar siswa pada siklus II dengan rata-rata kelas 83,91 dan semua siswa sudah mampu mencapai KKM yang ditetapkan sekolah yaitu 75. Nilai tertinggi pada siklus II adalah 94 dan nilai terendah adalah 78. Dari 23 siswa sebanyak 5 siswa memperoleh nilai 94, 3 siswa memperoleh nilai 88, 3 siswa memperoleh nilai 84, 4 siswa memperoleh nilai 80, 8 siswa memperoleh nilai 78. Peningkatan hasil belajar siswa yang terjadi dalam siklus I dan II dapat tergambar oleh grafik sebagaimana berikut:

Gambar 3 Grafik Ketuntasan Hasil Belajar Siklus I, Siklus II

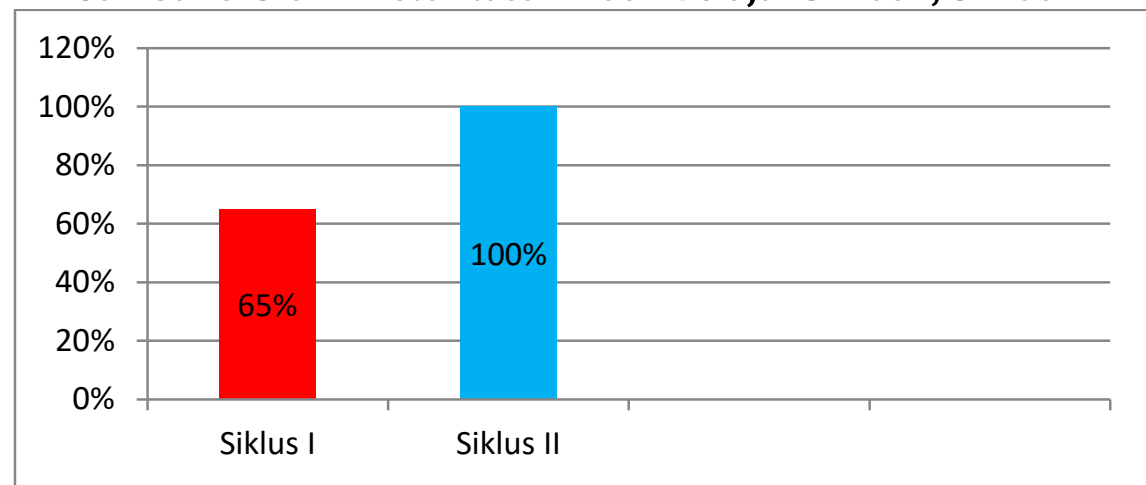

Pada gambar diatas dapat dilihat adanya peningkatan hasil belajar siswa. Perolehan nilai rata-rata setiap siklus selalu meningkat yakni siklus I (65\%), dan siklus II meningkat menjadi (100\%). Secara umum dapat dilihat bahwa sudah terjadi peningkatan hasil belajar mata pelajaran Alquran Hadis di materi Surah Al-Kafirun dengan menggunakan Metode Tahfiz.

\section{PENUTUP}

Berdasarkan pembahasan pada bab-bab sebelumnya dalam skripsi ini, maka dapat disimpulkan sebagai berikut: 
1. Penerapan Metode Tahfiz yang baik dalam meningkatkan hasil belajar siswa pada mata pelajaran Alquran Hadis di kelas II MI Raudhatul Ma'arif Muara Bungo ialah metode tahfiz teknik talqin.

2. Melalui penerapan Metode Tahfiz Teknik Talqin ini telah mampu meningkatkan hasil belajar siswa pada Bab Surah Al-Kafirun dalam pelajaran Alquran Hadis. Hal ini terlihat pada data-data yang ditampilkan menunjukkan perubahan yang signifikan terhadap hasil belajar siswa. Peningkatan itu tampak pada ketuntasan hasil belajar siswa dari siklus I ke siklus II. Pada akhir siklus I sebanyak 65\% atau 15 siswa yang berhasil mencapai dan melewati KKM yang ditetapkan. Pada siklus II setelah dilakukannya perbaikan, maka terjadi peningkatan sehingga jumlah siswa yang mencapai KKM menjadi 100\% atau 23 siswa. Dengan demikian, dapat disimpulkan bahwa penerapan metode tahfiz teknik talqin telah dapat meningkatkan hasil belajar siswa pada Bab Surah al-Kafirun mata pelajaran Alquran Hadis di kelas II Madrasah Ibtidaiyah Raudhatul Ma’arif Muara Bungo.

\section{Daftar Pustaka}

A. Wahab Jufri. Belajar Dan Pembelajaran Sains: Modal Dasar Menjadi Guru Profesional. Bandung: Pustaka Reka Cipta, 2017

Alpiyanto. Menjadi Juara dan Berkarakter. Bekasi: PT. Tujuh Samudra, 2013

Departemen Pendidikan dan Kebudayaan. Kamus Besar Bahasa Indonesia. Jakarta: Balai Pustaka, 2005

Fathin Masyhud dan Ida Husnur Rahmawati. Rahasia Sukses 3 Hafizh Qur'an Cilik Mengguncang Dunia. Jakarta : Zikrul Hakim, 2017, Cet.ke-4

Frandy Pratama, Firman, Neviyarni, “Pengaruh Motivasi Belajar IPA Siswa Terhadap Hasil Belajar Di Sekolah Negeri" dalam Edukatif : Jurnal Pendidikan, vol. I, no. 3

Kunandar. Penilaian Autentik. Jakarta: PT Raja Grafindo Persada, 2013 
M.Arifin. Ilmu Pendidikan Islam. Jakarta: Bumi Aksara, 2001, Cet.Ke-5

Madrasah Ibtidaiyah (MI) Raudhatul Ma'arif. Dokumen I KTSP Kurikulum 13. Muara Bungo: Raudhatul Ma’arif, 2018

Mahmud Yunus. Kamus Arab-Indonesia. Jakarta: Hidakarya Agung, 2000

Ngalim M. Purwanto. Prinsip-Prinsip dan Teknik Evaluasi Pengajaran. Bandung: PT.Remaja Rosdakarya, 2004

Paizaluddin dan Ermalinda. PenelitianTindakan Kelas (Classroom Action Research): Panduan Teoritis dan Praktis. Bandung: Alfabeta, 2016, cet.3.

Poerwadarminto. Kamus Besar Bahasa Indonesia. Jakarta: Bina Aksara, 2002.

Pustaka Pembinaan dan Pengembangan Bahasa Depdikbud. Kamus Besar Bahasa Indonesia. Jakarta: Balai Pustaka, 2003 Cet ke-4.

Sa'dullah. 9 Cara Praktis Menghafal Al-Qur'an. Jakarta: Gema Insani, 2000

Salafuddin AS. Ngaji Metal Metode Talqin . Jakarta: Wali Pustaka, 2018, Cet.1.

Taniredja.T, dkk. "Pendidikan Kewarganegaraan di Perguruan Tinggi Muhammadiyah. Bandung: Alfabeta, 2010

Wiwi Alwiyah Wahid. Cara Cepat Mebaca Al-Qur'an. Yogyakarta: Diva Press, 2014, Cet.ke-4. 